\title{
Minorities in Postcolonial Transitions: The Ndebele in Zimbabwe
}

\author{
Khanyisela Moyo \\ Lecturer, Transitional Justice Institute, University of Ulster, United Kingdom
}

\begin{abstract}
This article argues that there is a legal and political basis for attending to concerns of ethnic minorities in postcolonial transitions. If left unattended, this issue may prompt members of minority groups to resort to preservative measures, including violence to the detriment of the security which is a fundamental objective of the transition. This reaction is often generated by an axiomatic fear of assimilation. The case of the Ndebele of Zimbabwe illustrates this. The article's position is confirmed by post-colonial state practice that implements minority rights and accords affected groups a right to self-determination or autonomy in tandem with liberal democratic reforms.
\end{abstract}

\section{Keywords}

minority rights; postcolonial transitions; self-determination; autonomy; the Ndebele; democracy

\section{Introduction}

The notion that the promotion and protection of the rights of persons belonging to minority groupings is a fundamental aspect of a democratic regime based on the rule of law is gaining wide acceptance. ${ }^{2}$ Outgoing regimes that make the transition to a liberal democracy or peace often harbour ethnic, cultural or religious communities that cannot peacefully co-exist. ${ }^{3}$ Differences between the majority

1) LLB (Hons), M.A, LLM. PhD, In addition to transitional justice, the author's research interests are in postcolonial legal theory, feminist legal theory, minority rights, law of international organizations, issues of collective security and economic, social and cultural rights. E-mail: k.moyo@ulster.ac.uk

2) "Report of the Secretary-General on the effective promotion of the Declaration on the Rights of Persons Belonging to National or Ethnic, Religious and Linguistic Minorities", 6 September 2005, UN Doc. A/60/333. For a discussion on self-determination generally, see A. Cassese, Self-Determination of Peoples: A Legal Reappraisal, (Hersch Lauterpacht, Memorial Lectures, 1995). See also the discussion in AP Vijapur 'International Protection of Minority Rights (2006) 43 (4) IS 367; D. Archibugi, 'A Critical Analysis of the Self-determination of Peoples: A Cosmopolitan Perspective.' (2003) 10 (4) Constellations. 488.

3) Examples in this regard include Northern Ireland and Afghanistan. Northern Ireland is discussed in this regard in C. Warbrick, and D. McGoldrick, 'The Northern Ireland Peace Agreement, Minority Rights and Self-determination, (1998) 47 ICLQ 943, C. Bell, C. Campbell and F. Ni Aolain, 'Justice Discourses in Transition.' (2004) 13 SLS 306; C. Bell and Cavanaugh, 'Constructive Ambiguity or Internal Self-determination? Self-determination, Group Accommodation and the Belfast Agreement', (19981999) 22 Fordham Int'l L.J.1345. For Afghanistan, see P. Marsden, Afghanistan: Minorities, Conflict, and the Search for Peace. (Minority Rights Group International, London 2001). 
and minority groupings normally arise when the latter are of the viewpoint that the state is not respecting, protecting or fulfilling their rights. ${ }^{4}$ This is more-so given that their numerical inferiority might preclude them from securing their interests through democratic processes. ${ }^{5}$ In some cases this tension could be the root cause of authoritarianism or war. ${ }^{6}$ Against this backdrop, regimes in transition to a liberal democracy apply international human rights norms on minority rights and the right to self-determination in their transitional framework. ${ }^{7}$

Even in those cases where minority concerns may be deemed peripheral to the conflict of the day, a history of violations of rights may preclude members of such groups from being part of a shared narrative of the conflict, and this gives rise to their demands for pre-emptive measures. Left unattended, these concerns can forestall the peace process. ${ }^{8}$ Such issues are bound to surface in transitional periods since these are times when various stakeholders are involved in mapping the destiny of their society. This is an exercise described by R. Teitel as both "backward "and "forward" looking."

Since 2000, international focus on Zimbabwe's racial divisions has been directed to the Government of Zimbabwe's experience with the "majority's" claim to land that had historically been unlawfully expropriated by the "white" colonial regime for the benefit of the dominant minority group. ${ }^{10}$ Superficially, the racial division suggests that black Zimbabweans are a homogenous unit. ${ }^{11}$ Yet the reality is that ethnic diversity is an integral cause of conflict in the country. ${ }^{12}$

Disgruntled black minority groupings exist within Zimbabwe. ${ }^{13}$ Unfortunately, there is no standardized research which has looked at whether different ethnic

4) D. Geldenhuys and J. Rossouw, 'The International Protection of Minority Rights', a special report compiled for F.W. de Klerk Foundation (2001), <http://www.fwdklerk.org.za>, accessed 10 June 2009.

5) Ibid., See also S. Wheatley, 'Deliberative Democracy and Minorities,' (2003) 14 (3) E.J.I.L 507.

6) Geldenhuys, and Rossouw, supra note 4. See also J. Abbink, 'Ethnicity and Constitutionalism in Contemporary Ethiopia,' (1997) 41 J. Afr. L. 159.

7) For an analysis, see Bell, Campbell and Ni Aolain, (2004), supra note 3. This is a contentious area of law. Relevant legal scholars are still to establish a link between minority rights and transitional justice. The closest authorities on the subject could be said to be writings on the nexus between the Northern Ireland Peace Process and self-determination.

8) For example, the concerns of Chief Buthelezi's Inkatha Freedom Party nearly threatened South Africa's transition to black majority rule. See H. Booysen, 'South Africa: In need of a federal Constitution for its minority peoples,' (1996-1997) 19 Loy. Int'l \& Comp. L. Rev.789; H.A. Strydom, 'Minority Rights Issues in Post-Apartheid South Africa, (1998) 19 Loy. L.A. Int'l \& Comp. L.J.873; B. Oomen, 'Group rights in post-apartheid South Africa - The case of the traditional leaders,' paper Presented at the 14th International Congress of Anthropological and Ethnological Sciences in Williamsburg, VA, USA (1998) On file with author).

9) R.G. Teitel, Transitional Justice (OUP, Oxford 2000).

10) For a discussion of the Zimbabwean land question, see E. McCandless the Case of Land in Zimbabwe; Cause of Conflict, Foundation of Sustained Conflict (Rowman and Littlefield, Oxford 2001).

11) Ibid.

12) See T. Ranger, The Invention of Tribalism in Zimbabwe, (MP, Gweru 1985).

13) In its first report to the Committee on the Elimination of Racial Discrimination (CERD), the government of Zimbabwe (goZ) promised to give statistics on land distributed to Ndebele and Shonas in its next 
groups benefited equally from the country's various land redistribution schemes. Nonetheless, the experience of other postcolonial societies has been that such group claims have not been limited to equitable distribution of land. ${ }^{14}$ They have also engendered advocacy for either external self-determination or some other form of territorially autonomous arrangements by some distinct groups. ${ }^{15}$

Unfortunately, debates on the scope, objective, extent and nature of state party obligations with respect to these rights persist. ${ }^{16} \mathrm{~A}$ number of pundits have addressed some of the related issues elsewhere. ${ }^{17}$ Thus, this article confines itself to the legal justification for and possible approaches to minority concerns in postcolonial transitions. It begins by presenting the legal framework. This legal basis is then applied to the postcolonial context and to the case of Zimbabwe with a particular focus on the Ndebele. ${ }^{18}$ This is followed by an analysis which looks at the role of international law and its potential for facilitating the gradual move towards peace. This section includes comparative materials from those post-colonial societies which have had to address similar concerns. The article concludes with viewpoints which are of relevance not only to Zimbabwe but also to other postcolonial societies.

\section{The Legal Framework}

Legal protection for minorities is found in customary international law and in regional and international human rights standards. ${ }^{19}$ Minority rights enshrined in a number of binding and non-binding regional and international human rights standards include, inter alia, a right to life, freedom from torture and cruel and inhuman treatment, freedom of movement, freedom of association, freedom of

report but it did not do so. See 9, Summary Record of the 1132 meeting: Zimbabwe. 12/04/96 CERD /C/SR.1132.

14) An example in this regard is South Africa, see S. Nadasen, 'Restitution, Reconstruction, Reconciliation and Redistribution: Land Reform - balancing the interests of the dispossessed, the homeless and development,' (1997) 8 Stellenbosch L. Rev. 360; M. Barry. 'Now another thing must happen: Richtersveld and the Dilemmas of Land Reform in Post-apartheid South Africa,' (2004) 20 S. Afr. J. on Hum. Rts. 355.

15) Ibid., For example, there is a link between the idea of group claims to land in South Africa's transition from apartheid rule and the Afrikaners' quest for territorial autonomy.

16) See G. Welhengama, 'The Legitimacy of Minorities' Claim for Autonomy through the Right to Selfdetermination,' (1999) 68 Nord J Int Law 413.

17) Ibid. See also J. Castelino, 'Order and Justice: National Minorities and the Right to Secession,' (1999) 6 Int J Minor Group Rights 389; W. Kymlicka, 'The Internationalization of Minority Rights,' (2008) 6 Int. Jnl. of Constitutional Law 1; M.K. Ado, 'Political Self-Determination within the Context of the African Charter on Human and People's Rights,' (1998) 32 J Afr Law 182.

18) For the origins of the Ndebele see J.R. Cobbing, 'The Ndebele Under the Khumalo' 1820-1896', Unpublished PhD Thesis, (UL, Lancaster 1976), S.J. Ndlovu - Gatsheni, 'Dynamics of Democracy and Human Rights Among the Ndebele of Zimbabwe', Unpublished PhD Thesis, (UZ, Zimbabwe, 2003a). 19) The historic background of minority protection is traced by P. Thornberry, International law and the rights of minorities (CP, Oxford 1991). See also G. Pentassuglia, Minorities in International Law - An Introductory Study, and (ECMI Handbooks Vol. 1 ECMI Handbook Series, Strasbourg 2002). 
religion and protection against non-discrimination in the enjoyment of economic, social and cultural rights, the latter including an inalienable right to the use of a minority language. ${ }^{20}$ As is the case with all human rights, the purposes of minority rights are to ensure equality amongst all residents of a country, to preempt conflict and advance democracy. ${ }^{21}$

State parties to the relevant human rights instruments referred to above have both negative and positive obligations with respect to minorities. ${ }^{22}$ For example, they must not violate minority rights to existence and integrity which are guaranteed in the International Covenant on Economic, Social and Cultural Rights (ICCPR) and other human rights standards. ${ }^{23}$ They must also enact relevant legislation so as to facilitate a group's quest for the preservation of its identity. ${ }^{24}$

Further clarification on the actual application of these norms including case studies can be found in the jurisprudence and General Comments of the United Nations (UN) treaty bodies. ${ }^{25}$ Insights can also be drawn from reports of the special procedures of the Human Rights Council which include the UN Working Group on Minorities. ${ }^{26}$

With respect to the rights covered under the ICESR, the monitoring committee has stated in a number of its general comments that there are three levels of a

\footnotetext{
20) These include, inter alia; Articles 2,7 and 21 UDHR, Articles, 25, 26, and 27 ICCPR, Articles, 1 and 5 CERD GA. res. 2106 (XX), Annex, 20 UN. GAOR Supp. (No. 14) at 47, UN. Doc. A/6014 (1966), 660 UNTS. 195, entered into force Jan. 4, 1969, article 2, CRC, GA. res. 44/25, annex, 44 UN. GAOR Supp. (No. 49) at 167, UN. Doc. A/44/49 (1989), entered into force Sept. 2 1990, The Council of Europe's Framework Convention for the Protection of National Minorities ETS 157; 2 IHRR 217 (1995), Article 1, Declaration on the Rights of Persons Belonging to National or Ethnic, Religious and Linguistic Minorities (1992), GA. res. 47/135, 47 UN. GAOR Supp. (No. 49), at 210, UN Doc A/ Res/47/135.

21) See preambles UDHR, UN Charter, Declaration on the Rights of Persons Belonging to National or Ethnic, Religious and Linguistic Minorities. Although, this is not a legal binding document, it does reflect the international community's views on the subject since it was adopted by a consensus. Further in Article 1 it provides that (1) States shall protect the existence and the national or ethnic, cultural, religious and linguistic identity of minorities within their respective territories and shall encourage conditions for the promotion of that identity. (2) States shall adopt appropriate legislative and other measures to achieve those ends. This spirit is also found in the 1990 Copenhagen Document of the Organization for Security and Co-operation in Europe which maintained that; $[\mathrm{r}$ ]espect for the rights of persons belonging to national minorities as part of universally recognized human rights is an essential factor for peace, justice, stability and democracy in the participating States. Also in 1992, the Organization for Security and Co-operation in Europe (OSCE) also established the High Commissioner on National Minorities as a pre-emptive mechanism for resolving ethnic tension.

22) Geldenhuys and Rossouw, supra note 4.

23) Ibid.

24) See for example, Schedule IV of South Africa’s Interim Constitution (Act 200 of 1993).

25) For an understanding of the work of this body and other existing mechanisms for dealing with minority rights see Report of the High Commissioner on the rights of persons belonging to national or ethnic, religious and linguistic minorities, E/CN.4/2004/75 (24 February 2004).

26) Ibid.
} 
state's obligation. ${ }^{27}$ These are to respect, protect and fulfil. ${ }^{28}$ The duty to fulfil includes both an obligation to facilitate and to provide minority rights. ${ }^{29}$

The implementation of the state's duty to fulfil has always been problematic, as it entails the according to minorities of special rights over and above the right to equality. ${ }^{30}$ Ethnic groups require such arrangements not only to preserve their identity but also to prevent the tyranny of the majority and violence, ${ }^{31}$ though it must be said that historically, there have always been competing views on the nexus between special arrangements for minorities and state stability. ${ }^{32}$ There has always been a well-founded fear that such arrangements could be a catalyst for a secessionist movement and, hence, a threat to state sovereignty. ${ }^{33}$ Thus, alternative ways of protecting minorities were suggested. ${ }^{34}$

For example, Marxist, liberal and socialist theorists of the late twentieth century believed that modernity would do away with ethnicity. ${ }^{35}$ In their view, increased urbanisation and literacy would create loyalties to states and replace tribal affiliations. ${ }^{36}$ Obviously, this school of thought was disproved by the proliferation of conflict which characterized the period after the 1960s. ${ }^{37}$

Jennifer Jackson Preece has also stated that at its inception, the UN human rights system was also based on an assimilative view of democracy. ${ }^{38}$ Human rights instruments obliged states to respect the individual rights of all citizens without any special provisions for minorities and indigenous people. ${ }^{39}$ The presumption then was that plural societies made up of disparate groups were a hindrance to the creation and maintenance of democratic establishments. ${ }^{40}$ Consequently all individuals were to be treated equally. ${ }^{41}$

\footnotetext{
27) See for example, 20, General Comment 15 of the Committee on Economic, Social and Cultural Rights (ESCR Committee) UN Doc. E/C.12/2002/11.

28) Ibid.

29) Ibid.

30) See J.J. Preece, 'Democracy, Minority Rights and Plural Societies: Pus ca change?' (2008) 2/2 Sociology Campus 609.

31) H.J. Steiner, 'Ideals and Counter Ideals in the Struggle over Autonomous Regimes for Minorities,' (1991) 66 Notre Dame L. Rev 1539.

32) Preece, supra note 30.

33) Welhengama, supra note 16.

34) Ibid.

35) R.R. Ludwikowski, 'Constitutionalization of Human Rights in Post-Soviet States and Latin America:

A Comparative Analysis,' (2004) 33 Ga. J. Int'l \& Comp. L.1.

36) Ibid.

37) Ibid.

38) Preece, supra note 30.

39) Ibid.

40) Ibid.

41) Ibid.
} 
This approach had its limitations since groups within a state may have varied expectations. ${ }^{42}$ There are those whose quest is for integration and others who wish to maintain and preserve their identity within or outside the state they inhabit. ${ }^{43}$

The principle of equality inspires both positive and negative conduct. ${ }^{44}$ This view is substantiated by the distinction which was made between the protection of minorities and prevention of discrimination by the UN Sub Commission on the Promotion and Protection of Human Rights (The Sub Commission) in its first session of $1947 . .^{45}$ The Sub Commission defined prevention of discrimination as the prevention of conduct which deprived groups or individuals of equal treatment if they so desired it. ${ }^{46}$ It was also explained that protection of minorities entails securing the rights of non-dominant groups who wanted to be treated equally, while acknowledging or permitting a measure of differential treatment for those minorities to maintain the characteristics which set them apart from the dominant group if this was their aspiration. ${ }^{47}$

The question then is whether minorities are legally entitled to autonomy or the realization of the right to external self-determination. This discussion cannot be divorced from that of the international legal definition of minorities.

\subsection{Defining Minorities}

There is no international consensus on the legal definition for minorities. ${ }^{48}$ It is not the ambition of this work to repeat the analysis produced by a number of pundits on this vexed question, but the issue is raised as a prelude to a discussion on its added significance in postcolonial contexts. ${ }^{49}$ Nonetheless, most legal renditions on the subject draw from a working definition proposed by the then Special Rapporteur on minorities, Francesco Caportoti in 1977. ${ }^{50}$

Francesco Caportoti explained that four requirements are to be met for a group composed of a state's nationals to be characterized as a minority in law. ${ }^{51}$ These are: numeric inferiority, non-dominance, common ethnic, linguistic or religious

\footnotetext{
42) Ibid.

43) Ibid., see also Kymlicka, supra note 17.

44) See D. Henrard, Devising an Adequate System of Minority Protection: Individual Human Rights, Minority Rights and the Right to Self-Determination, (MNP, The Hague/Boston/London 2000).

45) Ibid.

46) Ibid.

47) Ibid.

48) The Council of Europe offered a legal definition in 1993 but since the focus of this study is on postcolonial contexts, no attention will be given to this understanding. See Council of Europe Parliamentary Recommendation 1201 (1993).

49) See for example, the discussion in Kymlicka, supra note 17.

50) F. Capotorti, Study on the Rights of Persons Belonging to Ethnic, Religious and Linguistic Minorities, (1977) UN Doc E/CN.4/Sub.2/384/Rev.1.

51) Ibid., see critique of these requirements by J. Castelino, 'Order and Justice: National Minorities and the Right to Secession,' (1999) 6 Int J Minor Group Rights 389.
} 
features that set it apart from the rest of the population and unity in its bid to preserve a collective group identity. ${ }^{52}$

In 1985, Jules Deschênes also gave a proposal which repeated all the requirements in this definition but differed in its claim that the group should be that of "citizens" who also have an objective of attaining both dejure and defacto equality with the rest of the population. ${ }^{53}$ The Human Rights Committee has, however, made it clear in its General Comment No. 23 that minorities who are to be protected by state parties are not necessarily citizens of a country. ${ }^{54}$ Rights provided for in Article 27 of the ICCPR are for all individuals within a state. ${ }^{55}$ These cannot be restricted to citizens as, for example, political rights which are provided for in Article 25.56

The issue of non-dominance also needs to be clarified. ${ }^{57}$ Frustrations which may lead minorities to seek equal treatment with the rest of society are varied, that is, they can either be political or economic. In some cases, dominant communities can exist as minorities. In Zimbabwe, prior to the fast track land reform program which commenced in 2000 , the white minority was in an economic dominant position. ${ }^{58}$ Yet, in the country's move from white minority rule to black majority rule they were accorded special measures to protect them from political marginalisation. ${ }^{59}$ This was also the case with white minorities in South Africa's transition from apartheid. ${ }^{60}$ Against this background, this work does not make a distinction between economic and political dominance of minorities.

The classic legal distinction between minorities and indigenous peoples also has to be highlighted as it has an added significance in postcolonial contexts. ${ }^{61}$ The term "indigenous peoples" refers to marginalized aboriginal persons who were originally in the state before the arrival of the dominant group. ${ }^{62}$ These are

\footnotetext{
52) Jules Deschênes restricts the ambit of minority protection to "nationals", thus all refugee protection is excluded since most refugees and migrant workers are often not nationals. J. Deschênes. (1985), Proposal Concerning a Definition of the Term 'Minority', UN Doc E/CN.4/Sub.2/1985/31 (1985).

53) Ibid.

54) 5.1 General Comment 23 of the Human Rights Committee UN Doc. CCPR/C/21/Rev.1/Add.5.

55) Ibid.

56) Ibid.

57) See R.A. Schermerhorn, Comparative Ethnic Relations: A Framework of theory and Research, (RH, New York 1970).

58) For a discussion of this issue see B. De Villiers, Land Reform: Issues and Challenges' A Comparative overview of experiences in Zimbabwe, Namibia, South Africa and Australia, (Konrad-Adenauer-Stiftung, Johannesburg 2003).

59) Southern Rhodesia: Report of the Constitutional Conference, Lancaster House: London, SeptDecember 1979 <http://www.rhodesia.nl/lanc1.html>, accessed 10 June 2009.

60) DeVilliers, supra note 58.

61) 4.3 Report of the African Commission on Human and Peoples' Rights Working Group of Experts on Indigenous Populations/Communities E/CN.4/Sub.2/AC.5/2005/WP.3.

62) S. Pritchard, 'The Rights of indigenous people to self-determination under international law,' (1992) 2(55) AboriginalLB 4. The characteristics of indigenous peoples are derived from; 50, J.M. Cobo, Study on the Problem of Discrimination against Indigenous Populations, (1983), UN Doc. E/CN.4/
} 
the people who do not want to be integrated and have collectively sought to preserve their culture and traditions. ${ }^{63}$ Self-identification as indigenous and members' acceptance of an individual's indegineity is seen as the most significant criterion for establishing the groups who can be said to be indigenous. ${ }^{64}$ This notion of individual self-identification as a member of the minority group has also been proposed by UN practitioners as a way of ensuring that cultures and traditions are not imposed on the unwilling. ${ }^{65}$ This is of utmost importance in issues dealing with indigenous people as the essence of their legal protection is based on understanding that they face extinction because of modern policies of ethnocide. $^{66}$

The most cited examples of indigenous people are American Indians and Aborigines in Canada. ${ }^{67}$ In the case of postcolonial Africa, groups which have been classified as marginalized indigenous peoples include the Berber of North Africa, Batwa of Central Africa and San of Botswana. ${ }^{68}$ Examples of minorities would be the Zulu of South Africa, Scottish of the United Kingdom and the North African immigrants of France. ${ }^{69}$

Asborn Eide and Erica-Irene Daes have stated that minorities and indigenous peoples have two different claims. ${ }^{70}$ Firstly, minorities allegedly seek to exercise individual rights but indigenous people want collective rights. ${ }^{71}$ Secondly, minorities' demands are said to be for non-discrimination and indigenous peoples' quest is for autonomy. ${ }^{72}$ This understanding is also reflected in relevant international standards. ${ }^{73}$ The ties in with the question as to whether minorities have a right to self-rule - either within or without the state's borders, and whether this is the best form of self-preservation.

Sub.2/1983/21/Add. 8, art. 1(1) (b), ILO 169; E.-I. Daes, Working paper on the concept of "indigenous people (1996), UN Doc. E/CN.4/Sub.2/AC.4/1996/2.

63) Ibid.

64) Ibid.

65) N.S. Rodley, 'Conceptual Problems in the Protection of minorities: International Legal Developments,' (1995) 17(1) HRQ 48.

60) R.A. Williams, 'Frontier of Legal Thought III: Encounters on the Frontiers of International Human Rights Law: Redefining the Terms of Indigenous Peoples' Survival in the World', (1990) DLJ 660.

67) Kymlicka, supra note 17.

68) Ibid.

69) Ibid., see also Booysen, supra note 8; H.A. Strydom, 'Minority Rights Issues in Post-Apartheid South Africa,' (1998) 19 Loy. L.A. Int'l \& Comp. L.J.873; Oomen, supra note 8.

70) A. Eide and E. Daes, Working paper on the relationship and distinction between the rights of persons belonging to minorities and those of indigenous peoples, (2000), E/CN.4/Sub.2/2000/10).

71) For an understanding of group and peoples' rights in human rights law see P. Jones 'Human Rights, Group Rights and Peoples' Rights,' (1999) 21(1) HRQ 80.

72) Ibid.

73) Minority rights instruments focus on promoting 'pluralism in togetherness' while documents on indigenous people concentrate on autonomy. These instruments also accord individual rights to minorities and group rights to indigenous peoples. Further, indigenous peoples are clearly given special rights to land and natural resources which is not the case with members of minority groups. 


\subsubsection{Minorities' Right to Autonomy and Self-determination}

Minorities who are concentrated in a geographic area of a sovereign state's territory have often stated that their demands for autonomy represent the pursuit of their right to self-determination. ${ }^{74}$ The legal validity of these claims is questionable although some pundits have attempted to advance them.

Jane Wright, for example, has argued that autonomous arrangements for minorities are an appropriate mechanism through which a state can fulfil its international legal obligation to extend a right to self-determination to all its peoples. ${ }^{75}$ In her view, the UN Declaration on Principles of International Law concerning Friendly Relations and Co-operation among States in accordance with the United Nations Charter calls for positive steps for correcting the inequitable distribution of power between majority and minority groups. ${ }^{76}$

This view can be contrasted with that of Asbjorn Eide. ${ }^{77}$ According to him, there is merit in the argument that groups living within a state have a right to internal self-determination, but not external self-determination or secession. In his view the Declaration of Friendly Relations defines the need for a representative government, and implies that all the people within a state have a right to elect their government. ${ }^{78}$ This is the democratic element of the right to internal selfdetermination. ${ }^{79}$

This cannot be taken as a basis for autonomous arrangements since by this definition minorities cannot be said to "peoples" who are entitled to external selfdetermination. ${ }^{80}$ "Peoples" who are entitled to external self-determination are the "demos" and not the distinct "ethnoses," the former term referring to all the inhabitants of a sovereign state who have a right to fully establish their territory. ${ }^{81}$ This applies to peoples who were colonized or subjected to foreign occupation, but the same cannot be said of "a group" within a state.

Eide also clarified in his 2001 study that minority groups, who live in a Sovereign state, including inhabitants from former colonies who claim that the government of a state is not representing all the people without discrimination, can

\footnotetext{
74) For meanings of self-determination, autonomy and the relationship between the two, see M. Weller Towards a general comment on self-determination and autonomy, (2005), E/CN.4/Sub. 2/AC.5/2005/ WP.5.

75) J. Wright 'Minority Groups, Autonomy, and Self-Determination' (1999) 19605.

76) Declaration on Principles of International Law Concerning Friendly Relations and Co-operation among States in accordance with the Charter of the United Nations, GA. res. 2625, Annex, 25 UN GAOR, Supp. (No. 28), UN. Doc. A/5217 at 121 (1970), as read with preamble UN Charter.

77) See A. Eide, 'Cultural Autonomy and Territorial democracy: a recipe for harmonious group accommodation', (2001) UN. Doc. E/CN.4/Sub.2/AC.5/2001/WP.4; G. Gilbert, Autonomy and minority groups - a legal right in international law? (2001) E/CN.4/Sub.2/AC.5/2001/CRP.5.

78) Eide, ibid.

79) A right to democracy is inherent in Article 21 of the UDHR, Article 25 of the ICCPR and in relevant regional conventions which gives everyone a right to take part in the government of his or her country.

80) Eide, (2001), supra note 77.

81) Ibid.
} 
approach the Committee on ICERD. ${ }^{82}$ With respect to ethnic groups' demands for autonomy, the Committee on ICERD explained in General Comment 21, that the territorial integrity of states is jealously guarded in international law. ${ }^{83}$ In its view:

[A] fragmentation of States may be detrimental to the protection of human rights, as well as to the preservation of peace and security. This does not, however, exclude the possibility of arrangements reached by free agreements of all parties concerned. ${ }^{84}$

Therefore, there is no sound legal basis for the view that autonomous arrangements for minorities' is derived from the right to self-determination. Neither is there any legal consensus as to whether minorities are "peoples" who have a right to freely establish their society. There is, however, an acknowledgement that autonomous arrangements that are implemented in good faith can be a mechanism for reducing conflict.

\subsection{Minorities in Transition}

It is axiomatic that concerns of minorities need to be a key aspect of the transitional agenda if the conflict or war has been caused by the state's violation of their rights. ${ }^{85}$ In 1993, as the then Special Rapporteur on minorities, Eide referred to this eventuality as a "situation involving minorities." 86 According to him, such situations occur when those who belong to minority groups have a general feeling of discontent associated with their group membership. ${ }^{87}$ The nature of their grievances can be assessed in terms of the demands that they make. ${ }^{88}$

The first demand is for equality of treatment. ${ }^{89}$ For example, in Northern Ireland (N.I), prior to the Good Friday Agreement of 1998, the minority Catholic community claimed that successive Unionist governments had subjected them to various forms of social, political and economic discrimination. ${ }^{90}$ The Northern Ireland example is very interesting because it also introduces a second set of

\footnotetext{
82) Article I of the ICERD included ethnic groups in its definition of those who are not supposed to be racially discriminated against.

83) General Comment 21 of the Committee on the Elimination of Racial Discrimination (CERD Committee) UN. Doc. A/51/18.

84) 6 , ibid.

85) For a discussion of these see C. Bell, On the Law of Peace-Peace Agreements and the Lex Pacificatoria, (OUP, Oxford 2008, 109-128).

86) 44, A. Eide, Possible ways and means of facilitating the peaceful and constructive solution of problems involving minorities, (1993), UN Doc E/CN.4/Sub.2/1993/34 and Add.1-4.

87) Ibid.

88) Ibid.

89) 45 , ibid.

90) See J. Ruane and J. Todd. The Dynamics of Conflict in Northern Ireland: Power, Conflict and Emancipation, (CUP, Cambridge 1996).
} 
demands which have been made by minority groups. ${ }^{91}$ This is the legally controversial and extreme claim for secession. ${ }^{92}$ In this context, groups will be demanding that they join their fellow members in another state or create their own new state in the area which they occupy.

Also, some governments have imposed rigid identities on people and have quashed any dissent by way of ethnic-cleansing. ${ }^{93}$ Thus, the third set of demands is for conditions which enable the minority to preserve its identity. ${ }^{94}$ These groups often seek the use of their language, religion and other aspects of cultural identity to maintain their culture. Some of these claimants have tied such requirements to the need for a degree of non-territorial autonomy, for example, the use of their own laws based on their own culture in family law matters. ${ }^{95}$

Finally, there are some minorities who have demanded territorial autonomy. ${ }^{96}$ This is a fundamental feature of polities where regions are accorded local selfgovernment. ${ }^{97}$ Popular examples of these structures include classic federalism, consociation, and arrangements of confederation, devolution and decentralization. ${ }^{98}$ This was illustrated by the 1995 Dayton Peace Agreement, which restructured Bosnia and Herzegovina along ethnic and religious lines. ${ }^{99}$

Similarly, a number of recent peace agreements include provisions for advancing self-determination claims of minorities. ${ }^{100}$ This state practice which has shaped comparative constitutional law can be construed as a legal justification for addressing minority concerns in transition. ${ }^{101}$ Indeed, in post-conflict societies, constitutions are often used either to facilitate the integration of disgruntled minorities or to accord them some degree of autonomy. ${ }^{102}$

In the context of transitional justice, legislation on group rights and political accommodation is a subset of constitutional justice. ${ }^{103}$ Citing case studies of the

\footnotetext{
91) Ibid.

92) 48, Eide, (1993), supra note 86 see also Castelino, supra note 17.

93) For a definition of ethnic cleansing see; 130, Final Report of the Commission of Experts Established Pursuant to Security Council Resolution 780 (1992) U.N. Doc. S/1994/674.

94) 46, Eide, (1993), supra note 86.

95) Ibid.

96) 47 , ibid.

97) C.E. Ehrlich, 'Democratic Alternatives to Ethnic Conflict: Consociationalism and Neo-Separatism', (2000) 26 Brooklyn J. Int'l L.447.

98) Ibid.

99) Dayton Agreement on Implementing the Federation of Bosnia and Herzegovina, Dayton, 10 November 1995, 35 I.L.M. 170 (1996).

100) Notable examples include the already-mentioned General Framework Agreement for Peace in Bosnia and Herzegovina (1995 Dayton Agreement), the Northern Ireland Peace Agreement (1998 Good Friday Agreement), The Bougainville Peace Agreement (2001), and the Constitutional Framework for Provisional self-government in Kosovo (2001). See Bell, supra note 85.

101) Ibid.

102) Ibid.

103) This issue is discussed in R.G. Teitel (2000) supra note 9 and R.G. Teitel 'Transitional Jurisprudence: The Role of Law in Political Transformation,' (1997) 106 Yale L.J. 2009.
} 
post-Nazi-Germany, Italy after Fascism and post-Stalin Russia; Professor Mauro Capelleti defines constitutional justice as a major legal justice-related solution to governmental subjugation. ${ }^{104}$ It denotes the creation of new constitutional provisions, institutions and processes for restraining and regulating the exercise of political power. ${ }^{105}$

Similarly, Professor Ruti Teitel argues that transitional constitutionalism differs from ordinary constitutionalism in that its purpose is not just to create mechanisms for limiting governmental power; it also constructs the transition. ${ }^{106}$ It is both backward and forward looking, that is, while constituting the new political order, it also responds to previous injustices. ${ }^{107}$ Further, she explains that transitional constitutions are not as fixed and sustained as ordinary constitutions. They are pro tempore, and include both interim provisions and some features which could be firmly established with time. ${ }^{108}$

Thus, constitutional provisions dealing with group rights and political accommodation serve two purposes in a transitional context. Firstly, these provisions assist by including threatened minorities in the political process, while assuring the same that there will be no governmental encroachment on their rights in future. ${ }^{109}$ Secondly, noting that disgruntled minorities can easily be mobilized for opposing change, these entrenchments can help in fostering peace and restoring or creating democracy depending on the transitional circumstances. ${ }^{110}$

The question then that should be addressed is whether concerns of minorities are a priority in other transitional contexts, where the cause of the conflict is not necessarily an ethnic conflict or "situation involving minorities." 111 Should societies transitioning from authoritarian rule focus on minimal guarantees which facilitate a society's move to peace and defer such special rights? ${ }^{12}$ Should the immediate concern be the move to a unitary democratic state which treats everyone equally? ${ }^{? 13}$ Are minority issues a time wasting distraction that puts an additional strain on the already limited resources of transitional societies? ${ }^{? 14}$ Is focus on

\footnotetext{
104) M. Cappelletti, 'Repudiating Montesquieu? The Expansion and Legitimacy of Constitutional Justice,' (1985-1986) 35 (1) Cath. U. L. Rev. 1. Bruce Ackerman has also stated that constitutional making underlies liberal revolutions (B.A. Ackerman, The Future of Liberal Revolution (YUP, New Haven 1992).

105) M. Cappelletti, (1985-1986), ibid. See also the discussion in C.L. Eisgruber, 'The Living Hand of the Past: History and Constitutional Justice', (1996-1997) 65 Fordham L. Rev. 1611.

106) Teitel, (2000), note 9 pps. 191-192.

107) Ibid.

108) Ibid.

109) R. Kolarova, 'Tacit Agreements in the Bulgarian Transition to Democracy: Minority Rights and Constitutionalism,' (1993) U Chi L Sch Roundtable 23 at 24.

110) Ibid.

111) L. Schlemmer, 'The Challenge of Political Transition in South Africa: Majority vs. Minority Rights,' (1991) 22(1) S Afr J Sociol.

112) Ibid.

113) Ibid.

114) Judy Barsalou has argued that; "resource constraints and mandate limits are inevitable features of
} 
minority rights in a situation where there is no responsible government capable of enforcing the law and respecting the rule of law somewhat misguided. ${ }^{115}$

Two counter-arguments to this can be made. ${ }^{116}$ Firstly, although the most apparent transitional priorities are democratization and economic advancement, transitional societies have in fact accorded legal recognition to the language and culture of majorities before prescribing any liberal democratic reforms. ${ }^{117}$ It is only minorities who are told that their own concerns ought to come second to those of the majorities. Deferral of the issue of special rights for minorities is often a means for assimilating affected groups thus making it difficult for them to make demands in future.

Secondly, even if one agrees that transitional priorities are minimal guarantees which restore security allowing the state to move to an economically advanced democracy, focus on minority rights cannot be said to be idle or superfluous. ${ }^{118}$ It ensures that nation-building is an inclusive process. ${ }^{119}$

It can also be argued that ignoring minority claims can be detrimental to the security that the transition aims for as this may prompt radical members of minority groups to resort to violence. ${ }^{120}$ Indeed, failure to respect the special characteristics of minorities has often created apprehensions by the groups concerned that they would be subsumed by majority communities. ${ }^{121}$ Thus some of these groups have resorted to preservative measures which include violence. ${ }^{122}$

Given all of this, the legal justification for addressing minority concerns in transition are the "hard" and "soft" law human rights standards which establish an intricate link between minority rights, self-determination and democratic governance. Another legal basis is state practice observed from recurrent provisions on minorities in post-war international, regional and domestic peace agreements. Indeed, it has been common practice for constitutional designs to respond to an affected group's quest for "self-determination" and democratic governance. ${ }^{123}$

\footnotetext{
transitional justice mechanisms and trauma relief programs". J. Barsalou 'Trauma and Transitional Justice in Divided Societies,' United States Institute of Peace, Special Report No. 135. (2005).

115) A.I. Sign, Democracy, Ethnic Diversity and Security in Post-Communist Europe (Praeger, Westport 2001).

116) Ibid., as read with W. Kymlicka, 'Justice and Security in the Accommodation of Minority Nationalism', in A. Dieckhoff (eds) The Politics of Belonging: Nationalism, Liberalism and Pluralism (Lexington, New York 2004).

117) Ibid.

118) Ibid.

119) Ibid., see also F. Ni Aolain, 'The Law of Under-enforcement in Transitional Societies,' University of Ulster, Jordanstown Campus, 2005 (On file with author).

120) Welhengama, supra note 16.

121) Ibid.

122) Ibid. See also Geldenhuys and Rossouw, supra note 4.

123) Ibid.
} 


\section{The Distinctive Features of Postcolonial Transitional Minority Questions}

\subsection{The Postcolonial Context}

As shown above, in the paradigmatic human rights discourse, minority concerns become a transitional issue in two contexts. This is either in the passage from an ethnic conflict to peace or when the inclusion of such concerns in the transitional agenda is part of a broad democratization process. This understanding which often starts with the state as the reference point has its limitations as it ignores an axiomatic cause of conflict in postcolonial societies. ${ }^{124}$ In these polities, ethnic conflict is often traced back to the colonial encounter which involved serious ethnocide. ${ }^{125}$

Roots of postcolonial ethnic conflicts can be explained through an analysis of these countries' three historic epochs. ${ }^{126}$ The first of these is the period when the colonialists created the postcolonial state. ${ }^{127}$ In order to create institutions for governance, the colonialists relied on ethnographic knowledge of the territories over which they had assumed power to govern each group along racial / ethnic lines. ${ }^{128}$ Absolute power was used to subordinate and incorporate diverse groups that had previously existed separately; yet in some cases there had been long standing tensions between these groups. ${ }^{129}$

In most cases, colonialists even fostered enmity between indigenous native ethnic groups by placing favoured minorities in positions of power. ${ }^{130}$ Examples of this practice are the Belgian policies which bestowed superiority status to the Tutsi in Burundi, the British alliance with the Sunni in colonial Iraq and France's policies which favoured the Alawi minorities in colonial Syria. ${ }^{131}$ In African partially settled colonies of Zimbabwe, South Africa, and Mozambique, the dominant minorities were the white settlers. In all these cases, discontent with the privileges and coercive policies of these dominant minorities were a rallying point

\footnotetext{
124) See M.K. Hong, 'A Genocide by Any Other Name: Language, Law and the Response to Darfur' (2008) 49 VJIL 235.

125) Ibid.

126) For a background to the challenges of postcolonial Southern Africa see L. Vail, The Creation of Tribalism in Southern Africa (Berkeley and Currey, London 1989), also available at <http://ark.cdlib.org/ark>, accessed on 10 June 2009.

127) Ibid., as read with Hong, supra note 124.

128) D.P.S. Goh, 'From Colonial Pluralism to Postcolonial Multiculturalism: Race State Formation and the Question of Cultural Diversity in Malaysia and Singapore,' (2008) 2(1) SOCO 232.

129) Ibid.

130) See also the Kateka dissenting opinion in; Armed Activities, Kooijmans separate opinion, 2005 I.C.J. $116,9$.

131) See M. Goldmann 'Does Peace Follow Justice or Vice Versa? Plans for Post-Conflict Justice in Burundi,' (2006), 30 Fletcher F. World Aff.137; M. Mutua, 'The Iraq paradox: Minority and Group Rights in a Viable Constitution,' (2006-2007) 54 Buff. L. Rev. 927 at 939; D. Pipers, 'The Alawi Capture of Power in Syria,' Middle Eastern Studies, (1989) <http://www.danielpipes.org> accessed on 10 November 2008 .
} 
for the majorities' nationalist struggles which largely evolved along communitarian religious, linguistic or ethnic lines. ${ }^{132}$

The second epoch which explains ethnic rivalry is the democratization processes and the transition from minority to majority rule. ${ }^{133}$ The quest for development and concerns amongst the postcolonial elite that their new states would be destabilized led to the adoption of the uti possidentis doctrine. ${ }^{134}$ The doctrine served two purposes, namely the prevention of frontier disputes among new states and to warn potential colonialists that there was no territory which was terra nullius. Groups which had previously existed separately were expected to live together in harmony. ${ }^{135}$ The prevailing view then was that discrimination was only an attribute of colonialism. ${ }^{136}$ This understanding had an added weight in former settler colonies where attempts at promoting difference had a sad resonance with the racist past where minority rights were inimical to democracy and associated with the entrenchment of white privileges. ${ }^{137}$

Notwithstanding these good intentions, the shift of power from dominant minorities to majorities did not necessarily usher in peace. ${ }^{138}$ This is because the terms of decolonization were a product of elite pacts. ${ }^{139}$ The practical effect of lack of consent in the formation of these states has been ethnic conflicts. Consequently, the postcolonial state's tendency to use force as a means of quashing dissent was a common feature of the period after decolonization. ${ }^{140}$ This failure to recognize and legally manage plurality has largely contributed to the classification of these states as being characterized by war, authoritarianism and dictatorship. ${ }^{141}$

Thus the third era in postcolonial contexts which created disgruntlement among minority groups and their related demands is the postcolonial era. Most of the grievances expressed by minorities are a protest against the policies of postcolonial states which had the effect of marginalizing or violating minority rights. ${ }^{142}$ Famous illustrations of this are the Rwandan genocide and the Ogoni's quest for self-determination. ${ }^{143}$

132) K. Nielsen, 'Liberal Nationalism, Liberal Democracies, and Secession, (1998) 48 U. Toronto L.J.253.

133) A. Anghie, 'Representing Culture, Translating Human Rights Symposium: Nationalism, development and the postcolonial state: the legacies of the League of Nations,' (2006) 41 TILJ 447.

134) See E. Hasani, 'International Law under Fire, Uti Possidetis juris: From Rome to Kosovo,' (2003)

Fletcher F. World Aff. 85.

135) Ibid.

136) Strydom, supra note 69.

137) Ibid.

138) C.R. Ezetah, 'International Law of Self-Determination and the Ogoni Question: Mirroring Africa's Post-Colonial Dilemma', (1996-1997) 19 Loy. L.A. Int'l \& Comp. L.J. 811.

139) Ibid.

140) For example, Nigeria and Congo experienced civil wars which were aimed at stopping a minority group from seceding soon after they became independent in 1960 .

141) Ezetah, supra note 138.

142) For the Darfur example, see Hong, supra note 124.

143) See Goldman, supra note 131 as read with Ezetah, supra note 138. 
Over and above all these concerns, postcolonial women experienced multiple forms of discrimination. ${ }^{144}$ During the colonial era, not only were they subjected to the same injustices as their male counterparts, they also had to endure further subjugation from postcolonial men who treated them thus as a way of regaining lost power. ${ }^{145}$ After independence, postcolonial governments are on record for having used women as targets of ethnic cleansing usually through systematic rape and sexual slavery. ${ }^{146}$ Unfortunately, the usual reaction to real or perceived ethnocide by patriarchs within the minority communities have been to subject women to harmful cultural practices. ${ }^{147}$

All these issues are illuminated by the concerns of the Ndebele people of Zimbabwe to be presented below.

\subsection{The Story of the Ndebele in Zimbabwe}

The Ndebele in Zimbabwe are mainly concentrated in the southern and western parts of the country. ${ }^{148}$ They have a strong group identity, born out of a culture and language that is fundamentally different from that of the majority Shona ethnic group. ${ }^{149}$ Their existence in this territory is not unusual in comparison with other post-colonial states, Zimbabwe is artificial and thus harbours distinct minorities who are inadequately represented in dominant narratives of its contested conflict. ${ }^{150}$ This is a secular country where issues of religion do not belong

144) D. Rajasingham, "On Mediating Multiple Identities: The Shifting Field of Women's Sexualities within the Community, State and Nation." in M.A. Schuler (eds), From Basic Needs to Basic Rights: Women's Claim to Human Rights. (WLDI, Washington DC 1995).

145) Ibid.

146) See, Final Report of Special Rapporteur on Contemporary Forms of Slavery on Systematic rape, sexual slavery and slavery-like practices during armed conflict, UN Doc. E/CN.4/Sub.2/1998/13 (1998).

147) D. Rajasingham, (1995), supra note 144.

148) For an understanding of the Ndebele identity see S.J. Ndlovu-Gatsheni, 'Nation Building in Zimbabwe and the Challenges of Ndebele Particularism,' (2008) 8 (3) AJCR 27.

149) See Minority Rights Group; World Directory of Minorities. <http://www.minorityrights.org> accessed on 11 November 2008.

150) J. Thondlana 'Using Indigenous languages for teaching and learning in Zimbabwe', Available at; $<$ http://jan.ucc.nau.edu/> accessed on 10 June 2009; F. Ndlovu, (2004) 'Is there anything minor about minority languages? Another look at the politics of languages in Zimbabwe', Paper presented at the Fourth International Conference on Preserving African Languages, Organized by the African Language Research Project, University of Maryland Eastern Shore, on 4-7 November 2004 <http://www.umes.edu/> accessed on 10 June 2009. The issue of minority culture and language rights in Zimbabwe was raised in I 27 of the concluding observations of the Human Rights Committee in its consideration of the initial and last report of the government of Zimbabwe to the Committee in 1998;1CCPR/C/SR.1649, CCPR/C/SR.1650, CCPR/C/SR.1650. See also, Summary record of the 1375th meeting: Zimbabwe. 14/03/2000. CERD/C/SR.1375, www.unhchr.ch/tbs/doc.nsf>, accessed on 10 June 2009; J. Muzondidya, 'Invisible subject minorities and the quest for justice and reconciliation in post-colonial Zimbabwe', in B. Raftopoulos and T. Savage (eds), Zimbabwe: Injustice and Reconciliation, Institute for Justice \& Reconciliation (IJR, Cape Town 2004); T. Barnes, 'Reconciliation, ethnicity and school history in Zimba- 
to the political arena, and have rather been left to individual conscience. ${ }^{151}$ Thus, the most relevant fault lines in any credible discussion on minority concerns in Zimbabwe are ethnic, cultural and linguistic. ${ }^{152}$

Within and in addition to two major ethnic groups, of approximately 65\% Shona speakers, 15\% Ndebele speakers, and tiny white and Asian populations, the country has fourteen other minority indigenous languages, namely: Kalanga, Nyanja Tonga, Nambya, Hwesa, Shangani, Barwe, Sotho, Venda, Chikunda, Xhosa, Sena, Tshawo and Tswana. Six of these languages are officially recognized. ${ }^{153}$ English is the principal language of instruction all over the country while Ndebele and Shona are also taught in areas where there are majority languages. ${ }^{154}$ There is no explicit constitutional reference to a right to culture, although a provision is made for the application of customary law in suitable circumstances. ${ }^{155}$ Nor is there a constitutional clause that obliges the state to ensure that all ethnic groups effectively participate in the political arena. ${ }^{156}$ The Constitution merely gives every adult of sound mind an individual right to vote. ${ }^{157}$

The Zimbabwean Constitution includes a liberal Bill of Rights which protects individuals against different forms of discrimination. ${ }^{158}$ A 2005 amendment added a proviso to the effect that affirmative action measures earmarked at correcting historic injustices cannot be said to be inconsistent with this nondiscriminatory clause. ${ }^{159}$ Clearly, this provision was meant to retrospectively give legal validity to the Mugabe regime's radical land program. This does not of course preclude its application to the marginalized minority groups and Zimbabwean women.

Thus the Zimbabwean Constitution does provide the legal framework for a society where law is applied to everyone and where there is universal suffrage. It, however, has two key shortcomings. Firstly, it is largely liberal and individualistic and does not explicitly provide for collective rights. Neither has it been a useful

bwe 1980-2002', in B. Raftopoulos and T. Savage (eds), Zimbabwe: Injustice and Reconciliation, Institute for Justice \& Reconciliation (IJR, Cape Town 2004).

151) Article 19 Constitution of Zimbabwe.

152) For minority rights generally, see Rodley, supra note 65.

153) See 11 Summary record of the GoZ initial report to Committee on CERD as read with 5 Core document forming part of the reports of the States Parties: Zimbabwe. 27/06/95. HRI/CORE/1/Add.55. The Shona who share a mutually intelligible language are not homogenous either since between their 5 major clans, Karanga, Manyika, Zezuru, Korekore and Ndau there is a diversity of customs, religious beliefs and dialects.

154) 4 Summary record of the GoZ initial report to Committee on CERD, Ibid.

155) S23 (3) Constitution of Zimbabwe.

156) See however, 11 Summary record of the GoZ initial report to Committee on CERD, supra note 153.

157) See Electoral Act - Incorporating all amendments as of June, 2008 and Constitution of Zimbabwe.

158) S23 Constitution of Zimbabwe prohibits discrimination 'by race, tribe, and place of origin, political opinions, colour, creed, sex, gender, marital status or physical disability.'

159) S23 (3g) Constitution of Zimbabwe, inserted by s. 4 of Act 5 of 2005 - Amendment No. 17 effective 14th September, 2005. 
tool for the legal protection of minorities who are marginalized politically and economically. This explains why this section will contribute to the collective claim by the Ndebele that they have something to contribute to Zimbabwe's governance but are excluded by the political system from doing so. This group concerns can be explained through an analysis of three phases which are the colonial era (1840-1980), period after independence (1980-1987) and the current epoch (1988-2010).

\section{3. $1840-1980$}

The Ndebele's strong sense of identity and unity can be traced to the arrival of king Mzilikazi from Zululand in present day Zimbabwe around $1840 .{ }^{160} \mathrm{On}$ arrival in the territory that was inhabited by the Shona under different chieftainships, King Mzilikazi founded the Ndebele state, which assimilated people of different origins, including some Shona. In the process, he is alleged to have raided and pillaged these tribes, stealing their cattle and women, thus giving rise to the traditional antipathy between the Shona and Ndebele. ${ }^{161}$

This history was to be manipulated by the colonialists as a part of a divide and rule strategy. ${ }^{162}$ They ensured that the legacy of Ndebele pillage and brutality was portrayed in history books. ${ }^{163}$ The Rhodesian narrative depicted the Shona as a weak and disorganized group that had not resisted imperialism because they needed protection from the better organized but militaristic and brutal Ndebele. This in turn allowed the white settlers to portray themselves as the civilized ushers of peace, Christianity, and order under the flag of the Union. ${ }^{164}$

These constructs fostered ethnic differences which were evident before and during the struggle against colonialism. ${ }^{165}$ Indeed, a number of Ndebele traditional leaders openly opposed the colonialists' decision to combine their kingdom with the various Shona chieftainships in $1900 .{ }^{166}$ As early as 1914 , The Matabele National Home Society was established to mobilize for an autonomous Ndebele homeland. ${ }^{167}$

Subsequently, there appeared to be a convergence of interest in struggling against white minority's occupation seen in the formation of a united main liberation movement, Zimbabwe African People's Union (ZAPU), under the leader-

\footnotetext{
160) See J.R. Cobbing (1976); S.J. Ndlovu - Gatsheni (2003a) supra note 18, see also R. Ford, 'Law, History, and the Colonial Discourse: Davies v Commissioner and Zimbabwe as a colonialist case study,' (2001) 32 How. L.J. 213.

161) Ndlovu-Gatsheni, supra note 18.

162) Ford, supra note 160.

163) Barnes, supra note 150.

164) Ibid.

165) Ibid.

166) See Centre for International development and Conflict Management (CIDCM), (2007), 'Data; Chronology for Ndebele in Zimbabwe,' <http://www.cidcm.umd.edu>, accessed on 10 June 2009.

167) Ndlovu-Gatsheni, (2003a) supra note 18.
} 
ship of Joshua Nkomo in 1961. ${ }^{168}$ The party was split into two in 1963 and The Zimbabwe African National Union (ZANU) was created. ${ }^{169}$ While both parties included Shona and Ndebele speakers, mutual resentment and regional recruitment practices led to the identification of ZAPU with Ndebele speakers and the strong alignment of ZANU with the Shona speakers. ${ }^{170}$

The unifying nature of the fight against racist rule, however, made it possible for ZANU and ZAPU leaders to frequent present joint positions at crucial conferences held in Lusaka (Commonwealth), Havana (Non-Aligned Movement), and lastly at the decisive London, Lancaster Constitutional Conference which ushered majority rule. ${ }^{171}$ Nonetheless, there were still calls for federation or separate existence which were championed by a party led by Chief Kayisa Ndebele who was seen as a paramount chief for Matebeleland. ${ }^{172}$

A less radical approach was adopted by Joshua Nkomo in his Lancaster house speech when he saw the prevention of a post-independence Zimbabwe where one ethnic, religious, tribal or other group dominated the rest of the population as a suitable transitional agenda. ${ }^{173}$ Unfortunately, the Lancaster House's deliberations only considered post-independence race relations between blacks and whites and not any disagreements that existed between blacks. ${ }^{174}$ The issue of minority rights was only scrutinized in as far as it conferred citizenship, property rights, entrenched overrepresentation in parliament for seven years and guaranteed civil service pensions to the economically significant white minority. ${ }^{175}$

\section{4. $1980-1987$}

In spite of the two parties' unity at the negotiating table, they fought the first independence elections separately and this culminated in victory for Robert Mugabe's ZANU PF. ${ }^{176}$ Even though these elections are mostly referred to as the

\footnotetext{
168) Ibid.

169) Ibid.

170) N. Bhebe and T. Ranger (eds), Soldiers in Zimbabwe's Liberation War: Volume One, (JC, London 1995). See also N. Bhebe, The ZAPU and ZANU Guerrilla Warfare and the Lutheran Evangelical Church in Zimbabwe, (MP, Gweru 1999).

171) This became possible after a unified alliance (Patriotic Front) of ZANU and ZAPU, jointly led by Joshua Nkomo and Robert Mugabe, was formed in 1976.

172) W. Olaleye, 'Political Parties and Governance in Zimbabwe,' EISA Occasional Paper No 18. (2004).

173) See Report of Southern Rhodesia, Constitutional Conference held at Lancaster House, London, September(Lancaster House agreement) December 1979,<http://www.zwnews.com/>, accessed on 10 June 2006; L. Mhlaba, 'The Transitional Period in Zimbabwe: The Constitution and Minority Rights', (1999) 19 (3) Politikon 101.

174) See Lancaster House agreement, ibid.

175) O.N. Musamirapamwe, 'The Evian Agreements on Algeria and the Lancaster Agreements on Zimbabwe: A Comparative Analysis', (1982) 12 G.A. Intl \& Comp. L. 15; K. Moyo, 'Ndebeles a minority that needs constitutional protection', Published by newzimbabwe.com, Zimbabwe's Diaspora online newspaper 15 February 2006 >http://www.newzimbabwe.com<, accessed on 10 June 2009.

176) For thorough discussions on this issue see D.G. Anglin 'Zimbabwe: Retrospect and Prospect' (1979-1980)
} 
country's first democratic elections, they were marred with intimidation and electoral violence. ${ }^{177}$ Most significantly, there was a tacit acceptance by key political actors that the country was divided into two nations. ${ }^{178}$ For example, when Robert Mugabe was confronted about the intimidation of Joshua Nkomo's campaigners in certain Shona-dominated constituencies, he said that part of Zimbabwe was his, Nkomo's country was in Ndebele speaking areas. ${ }^{179}$ Indeed, in line with Robert Mugabe's notion of his country and "Nkomo's country" the distribution of seats by province demonstrated that voters elected their candidates on regional, linguistic and ethnic lines. ${ }^{180}$

This reality was not factored in the post-independence review of national policies and legislation which was confined to racially discriminatory laws. ${ }^{181}$ There were also a number of measures adopted for putting racial discrimination to an end. ${ }^{182}$ The new regime focused on creating a multiracial society and eliminating tensions between whites and blacks. ${ }^{183}$ There was no similar drive towards preempting ethnic tensions amongst the indigenous population. ${ }^{184}$

While the government became popular abroad for extending a hand of forgiveness and reconciliation to ex-colonialists, this was not the case domestically. ${ }^{185}$ For example, soon after independence, former ZAPU liberation war heroes complained of discrimination and that they were not given meaningful political positions. ${ }^{186}$ These concerns were compounded by the perception that the central government ignored the Ndebele region's economic and developmental needs. ${ }^{187}$

Between 1983-1987 a North Korean-trained army unit was deployed to Ndebele speaking areas, supposedly to deal with terrorists who were attacking white farmers. These dissidents or terrorists were said to be the South African apartheid regime's agents for destabilizing a new black government. ${ }^{188}$ Approximately

35 ILJ 663; R.O. Matthews 'From Rhodesia to Zimbabwe: Prerequisites of a Settlement' (1989-1990) 45 ILJ 292.

177) D. Smith, and C. Simpson, Mugabe (Sphere, London 1981, 181).

178) Ibid., at 187.

179) Ibid.

180) Supra note 176.

181) Mhlaba, supra note 173.

182) Ibid.

183) Ibid.

184) Ibid.

185) See R. Carver, 'Zimbabwe: A Break with the Past? Human Rights and Political Unity'. (Africa Watch, NY 1989) as read with E. Mkwananzi, 'Responsibility for enforced disappearances under International law: the case of Matebeleland 1983-1987', Unpublished PhD Thesis, University of Zimbabwe, 1997 (on file with author).

186) Catholic Commission for Justice and Peace (CCJP) and the (Legal Resources Foundation (LRF), Breaking the Silence, Building The Peace: Report on the Disturbances in Matebeleland and the Midlands, 1980 to 1988, (CCJP\& LRF, Harare 1997). See also N. Kriger, 'Veterans' pensions in Zimbabwe; dispute resolution and nation-building,' (2005), 20 Ohio St. J. on Disp. Resol. 249.

187) See A. Mutembwa, 'Water and the potential for resource conflicts in Southern Africa,' Occasional Paper No. 3, Global Security Fellows Initiative, University of Cambridge, (1998).

188) Ibid. 
20,000 people are said to have been killed. ${ }^{189}$ This episode is widely referred to as the Gukurahundi, a Shona word which means 'the rain that washes away the chaff from the last harvest, before the spring rains'. ${ }^{190}$ According to Sabelo NdlovuGatsheni:

[i]t seemed the last harvest was the achievement of independence, the 'Matebeleland region and the Ndebele were the chaff that was supposed to be washed away and the 'spring rain' was the establishment of the one-party state in Zimbabwe. ${ }^{191}$

This view is widely held and is the basis for a growing movement which is campaigning for the Gukurahundi to be officially recognized as a genocide. ${ }^{192}$ It also has to be highlighted that the formal end of these disturbances was brought about by the unity accord of December 1987(1987 GNU). ${ }^{193}$ This agreement issued a general amnesty to the dissidents, put Joshua Nkomo in the position of a half vice-president and merged other ZAPU leaders into ZANU-Pf, thereby creating a one-party state. ${ }^{194}$ Although the (1987 GNU) facilitated the move from violence to peace, it failed to promote reconciliation between the two communities since a blanket amnesty was imposed without any state acknowledgement of culpability. ${ }^{195}$

It has been difficult for victims and their families to forgive and forget since no official truth about the reasons for, or the extent and nature of the atrocities committed has been established. The amnesty which followed the Gukurahundi atrocities gave rise to a perception that the GoZ (Government of Zimbabwe) can act with impunity and thus contribute to a fear among the Ndebele that similar acts may be perpetrated against them again. ${ }^{196}$

\section{5. $1988-2010$}

It would appear that the 1987 GNU was not fully embraced by the Ndebele community. This observation is supported by the fact that their region became a stronghold for the Movement for Democratic Change (MDC), which was formed in 1999 , out of a coalition of dissenting voices. ${ }^{197}$ The region was further alienated

\footnotetext{
189) CCJP \& LRF, Harare, supra note 186.

190) S.J. Ndlovu-Gatsheni, 'The Post-Colonial State \& Matebeleland: Regional Perceptions of CivilMilitary Relations, 1980-2002' in R. Williams, G. Cawthra and D.A. Abrahams (eds), Ourselves to Know: Civil-Military Relations and Defence Transformation in Southern Africa, (ISS, Pretoria (2003b).

191) Ibid.

192) See Crimes against Humanity Zimbabwe (CAHZ); <http://cahz.org/genocide>, accessed 13 November 2008 .

193) Mkwananzi, supra note 185.

194) The one party state came about because the government of national unity coincided with the end of the seven year constitutional moratorium on white overrepresentation in Parliament.

195) CCJP \& LRF, Harare, supra note 186.

196) Ndlovu-Gatsheni, (2003b), supra note 190; Carver, supra note 185.

197) See Movement for Democratic Change online, <http://www.mdczimbabwe.org/> accessed 10 June 2009.
} 
by the fact that just before the 2002 presidential elections, the ruling ZANU Pf party threatened some Ndebele areas with starvation if they voted for MDC. ${ }^{198}$ In the same year Shona speaking election monitors were deployed to the region to monitor elections to the chagrin of the locals. ${ }^{199}$

Ethnic tensions also surfaced when MDC split on the 12th of October 2005. ${ }^{200}$ In a self-evident ingenuity aimed at garnering support from the majority Shona group, the leadership of the largely Ndebele splinter group scouted for a Shona speaker, Professor Arthur Mutambara who became the leader of their MDC faction. ${ }^{201}$ This decision confirmed the Ndebele perception that they will always be marginalized politically. ${ }^{202}$ This is more so since the power sharing deal signed on the 15th of September 2008 does not have a Ndebele signatory. ${ }^{203}$

Fears that the Ndebele community cannot freely establish their society have manifested themselves in the emergence and growing popularity of two political groups from Matebeleland. These are the Patriotic Union of MaNdebeleland (PUMA) and Mthwakazi People's Convention (MPC). They were both born out of discontent with the colonial state formation, marginalization of the Ndebele by the postcolonial state, the legacy of state violations of this group's rights and a genuine fear of assimilation. While both groups require territorial autonomy, they differ in the sense that MPC is much more radical as its quest is for secession.

In addition to calls for accountability and autonomy, there are demands that the region be administered by local civil servants instead of the current Shona administrators. ${ }^{204}$ Economically speaking, claims are for increased opportunities and more public spending in the region. ${ }^{205}$ Culturally, many would like to see the

\footnotetext{
198) Amnesty International, Zimbabwe Power and hunger - violations of the right to food, (Amnesty International, International Secretariat London, 2004) <http://web.amnesty.org/>, accessed on 10 January 2005; K. Moyo, Just ends, Just means. ..., is starving a nation for political gain a crime against humanity? The Zimbabwean Case 2000-2003, (Unpublished Masters Thesis, University of Oslo, 2003).

199) See Centre for International Development and Conflict Management (CIDCM), (2003), 'Assessment for Ndebele in Zimbabwe', <http:// www.cidcm.umd.edu/papers.asp> accessed on 10 June 2009. 200) See International Media (2005), 'Opposition Splits While Zimbabwe Continues to Slip,' <http:// www.idu.org> accessed on 10 June 2009.

201) See Movement for Democratic Change (UK), 'Bulawayo welcomes Professor Mutambara; MDC President', <http://www.mdcuk.com/Starrally.htm>, accessed on 10 June 2009.

202) Moyo, supra note 175.

203) Agreement between the Zimbabwe National Union Patriotic Front(ZANU - PF) and the two Movement for Democratic Change (MDC) Formations, on Resolving the Challenges Facing Zimbabwe, Done in Harare on the 15th of September 2008, <http://www.info.gov.za> accessed 29 December 2008. This document has since been gazetted as part of the country's Constitutional Amendment (No. 19) Bill, 2008. Before the signing of this document key political actors had been negotiating a political impasse ever since the disputed March 2008 elections. The first breakthrough in those negotiations was in the form of a Memorandum of Understanding between ZANU - PF and the two factions of MDC which was signed on 21 June 2008, <http://www.reliefweb> accessed 29 December 2008.

204) CIDCM, 'Data: Assessment for Ndebele in Zimbabwe' <http://www.cidcm.umd.edu> accessed 10 June 2009.

205) Ibid.
} 
promotion of and respect for the Ndebele lifestyle and language rights with a change in the perceived Shona-bias of civil servants who administer the area. ${ }^{206}$

\section{The Role of International Law; How to Read Zimbabwe's Experience with the Ndebele Question}

The Ndebele demands invoke two legal conundrums which were pointed out in the normative framework section. The first is the definition issue as it affects the nature of rights conferred on this group. The second is the controversial question whether minorities have a right to self-determination as well as the issue of whether they have a legal right to autonomy.

\subsection{Are the Ndebele a "Minority" in International Law?}

Both the Ndebele and the Shona were referred to as natives in Rhodesia although the Ndebele state was only formed four decades before the arrival of the colonialists. ${ }^{207}$ The majority Shona are also not the original occupiers of the territory which is said to have been inhabited by the Khoi San before the latter's existence. However, both the Ndebele and the Shona cannot be neatly classified as indigenous as members of the two communities have actively participated in Zimbabwe's modernization process and have largely done away with primordial lifestyles.

Nonetheless, it is indisputable that both groups have an attachment to the territory referred to as Zimbabwe as their homeland. They largely view groups from neighbouring countries, such as labourers from Mozambique who were brought in during colonialism as immigrants and foreigners. ${ }^{208}$ Interestingly, the "foreigner" label has also been extended to the Ndebele and minority white population by some sectors of the Shona population yet these groups largely see themselves as homeland minorities. ${ }^{209}$

The concept of "minority" is problematic not only in Zimbabwe but in postcolonial Africa as a whole since most of these countries are composed of several distinct groups, and in some cases no single group can be classified as a majority. ${ }^{210}$ For example, Zambia has at least 70 ethno-linguistic units and none of these

\footnotetext{
206) Ibid.

207) D. Jeater, 'Speaking like a native: Vernacular languages and the state in Southern Rhodesia, 18901935,' (2001) 42 (3) J Afr Hist 449.

208) Muzondidya, supra note 150.

209) See S. Ndlovu-Gatsheni, 'Do Zimbabweans Exist?' The Ferguson Centre for African and Asian Studies

(07 February 2008) <http://www.open.ac.uk> accessed 10 June 2009.

210) See reports of a series of seminars held on "Multiculturalism in Africa: peaceful and constructive group accommodation in situations involving minorities and indigenous peoples," held in Arusha, Kidal and Gaborone, UNDocs.E/CN.4/Sub.2/AC.5/2000/WP.3;E/CN.4/Sub.2/AC.5/2000/WP.3andE/CN.4/ Sub.2/AC.4/2002/4.
} 
groups form a majority. Another interesting example is Nigeria which has three major ethnic groups and numerous minorities. ${ }^{211}$ These minorities can be further divided into either peripheral minorities who are found in each of the country's regions and "marginal" groups who are minorities in their respective regions but have ties with majority ethnic groups in countries which share the border with Nigeria. $^{212}$

As has been stated above, Zimbabwe has three major ethnic group and numerous linguistic minorities who have been voluntarily and forcefully assimilated into these three groups. ${ }^{213}$ In the case of the Ndebele, some of the people who make up this group speak the Sotho, Tswana, Khalanga, Venda and Tonga languages that are also spoken by some groups in neighbouring South Africa, Botswana and Zambia. ${ }^{214}$

This is not unusual since Africa's borders are artificial. There are some groups which are a marginalized minority in one country and a majority in another. For example, the Hutu in Burundi complain of marginalization by the Tutsi dominated regimes that have brutalized them in the past. ${ }^{215}$ To the contrary, the Tutsi in Rwanda fear extermination by the Hutu and their claims are justified by the 1994 genocide. $^{216}$ Further, the label of "minority" has posed problems in postcolonial contexts as a number of African minorities, who do not want to be considered as such, as this characterization is associated with marginalization and in some cases confused with inferiority. ${ }^{217}$

These difficulties can be attributed to the fact that the definition of minorities has been developed by Western pundits who are largely influenced by the concerns and experiences of their own societies. ${ }^{218}$ Contemporary Western minorities are immigrants and "homeland minorities" whose principal demands are for equality of treatment. ${ }^{219}$ Also, in countries like Canada, Australia and the United States of America, indigenous people can be clearly identified as those marginalized groups who existed before the arrival of the dominant tribe. These groups have resisted any efforts at integration and it has been discovered that they have a lot of poverty issues hence the international legal emphasis on their rights to land or natural resources. 220

\footnotetext{
211) C. Ezetah, supra note 138, as read with E.E. Osaghae, 'Managing multiple minority problems in a divided society; the Nigerian experience,' (1998) 36 (1) J Mod Afr Stud 1.

212) Osaghae, ibid.

213) Muzondidya, supra note 150.

214) Ibid.

215) Goldmann, supra note 131.

216) Ibid.

217) Eide, (1993), supra note 86.

218) See Kymlicka, supra note 17.

219) Ibid.

220) Ibid.
} 
This characterization cannot fit neatly in the postcolonial context as all postcolonial natives could be said to be indigenous since they are marginalized groups which existed before the advent of the colonial state. ${ }^{221}$ For example, in its 2002 report to the Committee on the Rights of the Child (CRC), Zambia stated that all its groups are indigenous, thus the UN classification of groups as either indigenous or minorities does not apply to its circumstances. ${ }^{222}$ This seems to be a common held view in postcolonial societies although these countries discriminate against and have given labels of "foreigner" or immigrant to those groups which were brought in their territories during colonial rule. ${ }^{223}$

The attitude that there is a difference between European minority issues and the postcolonial context has also been manifested in the work of the ACHPR. ${ }^{24}$ It is unfortunate, though, that this quest for context specific solutions has not necessarily resulted in the promotion of group rights for postcolonial minorities. It has rather been used to tacitly approve African states' preference for assimilation as a nation-building policy. ${ }^{225}$

\subsection{Is the Ndebele Quest for Autonomy and Self-determination Legitimate?}

It has been explained above that in the period after independence the government of Zimbabwe attempted to forcefully assimilate the Ndebele as part of its nation building project. ${ }^{226}$ Not only was this method inimical to the international human rights ideals invoked by nationalists in their quest for independence, it also contravened Zimbabwe's own Constitution which contains a justiciable Bill of rights. ${ }^{27}$ Interestingly, the goZ has acknowledged in its reports to the human rights treaty bodies that the Ndebele have been marginalized. ${ }^{228}$ As Mr. Chinamasa put it to the Human Rights Committee:

\footnotetext{
[s] ince people tended to vote for political parties representing their own ethnic groups, the Ndebele would never have had the opportunity to share power without the Unity Agreement. A further benefit of the Government of National Unity had been that politicians of Ndebele origin had begun to see issues from a national rather than a minority perspective. ${ }^{229}$
}

\footnotetext{
221) Ibid.

222) Zambia State Party Report to Committee on CRC, U.N. Doc. CRC/C/11/Add.25 19/11/2002.

223) J. Muzondidya, (2004) supra note 150.

224) 230-235 Eide, (1993) supra note 86.

225) 230-235, ibid.

226) Ndlovu-Gatsheni, (2003b) supra note 190.

227) Chapter 3, Constitution of Zimbabwe.

228) See 20, Core document forming part of the reports of the States Parties: Zimbabwe. 27/06/95. UN Doc.HRI/CORE/1/Add.55 as read with 45, Summary record of the 1375th meeting: Zimbabwe. 14/03/2000. UN Doc. CERD/C/SR.1375.

229) UN Doc. HRI/CORE/1/Add.55, ibid.
} 
Inherent in this statement is an acknowledgement that the Ndebele's numeric inferiority precludes them from effective participation in the country's political arena. ${ }^{230}$ There is, however, a failure to appreciate the meaning of effective political participation. The message conveyed is that it would be desirable if most Ndebele people see the issue from a national and not minority rights' perspective. Also, the goZ does not acknowledge responsibility for the human rights violations it committed during the Gukurahundi. This strengthens the case for the Ndebele demands for both internal and external autonomous arrangements as a way of preserving group identity.

Unfortunately, international law does not give communities like the Ndebele a collective right to either internal or external self-determination. ${ }^{231}$ It has already been pointed out that existing liberal Eurocentric legal standards are inadequate in so far as collective rights are concerned. ${ }^{232}$ So far the only protection to minorities which is binding on state parties is based on the weak Article 27 of the ICCPR that vests the right to individuals and not groups. ${ }^{233}$ This critique also applies to ICCPR Article 1 on self-determination and Article 25 on political participation since these are abstract individual rights which are of universal and not substantial local application. ${ }^{234}$

There is a well-grounded fear in international law that recognition of collective rights may lead to violation of rights of either individuals or sub-groups within those enclaves. It is also fair to note that reluctance in embracing commutarianism can be useful in preventing the appropriation of culture by extremists for chauvinist purposes. ${ }^{235}$

Nevertheless, international law cannot offer the Ndebele adequate protection since it considers state boundaries as sacrosanct and would rather all those who occupy the nation-state are integrated within the nation-state despite their differences. This understanding derives from Western liberal scholars' assumptions that minorities want to be equal with the rest of the society. 236

However, the point still remains that this legal framework has been crafted and developed without any serious regard to views or experiences of the postcolonial.

\footnotetext{
230) Ibid.

231) See Pritchard, supra note 62.

232) Ibid.

233) For a discussion on collective and individual rights as it relates to minorities see M. Jovanovic, 'Recognizing minority identities through collective rights' (2005) 27 HRQ 625.

234) See J.E. Oestreich. 'Liberal Theory and Minority Group Rights' 21(1) Human Rights Quarterly, (1999) pp. 108-132; P. Jones, 'Human Rights, Group Rights and People's Rights', (1999) 21(1) HRQ 80. The weakness of the international legal protection is clearly evident in the Human Rights Committee's systematic refusal to deal with complaints based on the collective right to self-determination on the basis that the Optional Protocol to the ICCPR(OP-ICCPR) is an individual complaints procedure. See Lubicon Lake Band v. Canada, Communication No. 167/1984 (26 March 1990), UN. Doc. Supp. No. 40 $(\mathrm{A} / 45 / 40)$ at $1(1990)$.

235) Rodley, supra note 65.

236) Kymlicka, supra note 17.
} 
It largely focuses on finding possible solutions to the problems of European minorities. ${ }^{237}$ For example, while integration with diversity which has been proposed by Professor Tom Hadden may be desirable in Northern Ireland because of the country's sad legacy of sectarianism, the same panacea cannot be prescribed for all postcolonial societies. ${ }^{238}$ In the case of postcolonial Africa, state disintegration can be prevented through guarantees of autonomy to disgruntled minorities who do not qualify as indigenous peoples. ${ }^{239}$

Will Kymlicka has explained that the UN approach and the Western society's practices only converge when it comes to the treatment of "new minorities." ${ }^{240}$ In the case of old or national minorities the difference is that the UN favours integration for all minorities, yet most developed Western states have long since accorded autonomous arrangements to their "national" minorities. ${ }^{241}$ This suggests that international law largely prioritizes contemporary challenges of the West and not those of postcolonial societies. ${ }^{242}$

Indeed, with the exception of a few contentious zones like Northern Ireland, Georgia and the Basque Country, most European countries have long since assured their ethnic minorities that they would not be forcefully assimilated. ${ }^{243}$ They have done so by according them some forms of autonomy. ${ }^{244}$ Thus it can be said that the current preoccupation of most of the developed Western World is the pre-emption of problems that might be heralded by the influx of immigrants who are the new minorities. ${ }^{245}$ Yet in the post colonial world, although, aspirations may vary in terms of degrees, the Ndebele of Zimbabwe, Kurds of Iraq, Southern Peoples of Sudan and Tamils of Srilanka require arrangements akin to those accorded to The Aland Islands of Finland, The Faeroe Islands and Greenland of Denmark and Scotland in the United Kingdom in the mid 20th Century. ${ }^{246}$

The Eurocentric character of the law has been acknowledged even at the UN. For this reason and since 2001 the UN WGM has been attempting to redress the imbalanced focus in the discourse of minority rights by organizing regional conferences in the postcolonial world. ${ }^{247}$

\footnotetext{
237) Ibid.

238) T. Hadden 'International and national actions for the protection of minorities - the role of the working group on minorities,' (2004) E/CN.4/Sub.2/AC.5/2004/WP.3.

239) See A. Mazrui, 'The African State as a Political Refugee: Institutional Collapse and Human Displacement,' (1995) IJRL (OAU/UNHCR Special Edition, C.R. Ezetah (1996-1997) supra note 138 and J. Bengoa, (2000), 'Existence and Recognition of Minorities,' UN.Doc E/CN.4/Sub.2/AC.5/2000/ WP.2.

240) Kymlicka, supra note 17.

241) Ibid.

242) Ibid.

243) Preece, supra note 30.

244) Ibid.

245) Ibid., as read with Kymlicka, supra note 17.

246) Ibid.

247) Bengoa, supra note 239.
} 
Unfortunately for postcolonial minorities, when it comes to the treatment of "national minorities" almost all regional bodies including their own, are not keen to have the state submit to binding legal procedures. ${ }^{248}$ In the case of postcolonial Africa, the term "minorities" was excluded in both the Banjul Charter and the ACHPR Working Group on Minorities. ${ }^{249}$ Even key African human rights actors have manifested a preference for an individualistic minority rights framework. ${ }^{250}$ For example, the Rwandan model which comprises of ethic quotas in public office and education has been critiqued for being racially discriminatory even though the essence of this system is to address the marginalization of the Hutu. ${ }^{251}$ This is part of the colonial hangover as any practice which seeks to give people differential treatment reminds the postcolonial of both the colonial "divide and rule strategy" and segregation. ${ }^{252}$

Therefore, while the majorities such as the Shona in Zimbabwe can enjoy their right to establish their society through the ballot box the same cannot be said of minorities. Unfortunately, it would be futile for the Ndebele to reject the dominant legal discourse as this is bound to be a lone battle. This is unlike the "peoples" struggles for independence from white colonial rule where the clear adversaries were former colonial masters. Postcolonial minorities' demands are much more complex. It is ambitious to expect states who are the subjects, actors and constructors of international law to support any efforts at undermining the state's existence. ${ }^{253}$ Thus postcolonial minorities face resistance from both former colonial masters and postcolonial states. This is not to ignore issues of interest which influence and sometimes lead to inconsistencies in state practice. ${ }^{254}$

Biafra's 1967 failed attempt at full independence attests to the futility of acting outside international law. ${ }^{255}$ Biafra's demands were based on pre-colonial serious cultural divisions, impact of colonial rule and the massacres of the Ibos by the Nigerian postcolonial state. ${ }^{256}$ The proposed state of Biafra however, differs from the Mthwakazi nation envisaged by the Ndebele since the kingdom of Mthwakazi existed independently from the Shona chieftainships before colonialism. ${ }^{257}$ The Ibo tribe has no history of separate existence from Nigerian as a nation. ${ }^{258}$

\footnotetext{
248) Ado, supra note 17.

249) Ibid.

250) Ibid., as read with 230-235, Eide, (1993) supra note 86.

251) Ado, supra note 17.

${ }^{252)}$ E.G. Irobi, 'Ethnic Conflict Management in Africa: A Comparative Case Study of Nigeria and South Africa,' (2005) <http://www.beyondintractability.org> accessed 10 October 2009.

253) Ado, supra note 17.

254) See D. Callahan 'Unwinnable Wars: American Power and Ethnic Conflict.' (Hill and Wang, NY 1998).

255) For a discussion of this and other examples of attempts at secession, see A. Heraclides, The Selfdetermination of minorities in international politics (Cass, London 1991).

256) Ibid., at 82 .

257) On the proposed Mthwakazi nation see Ndlovu-Gatsheni, supra note 148.

258) Callahan, supra note 254.
} 
Nonetheless, even in the case of Eritrea which did secede in 1991, the right to external self-determination was won after an armed struggle. ${ }^{259}$ Indeed, most minorities who have managed to get concrete concessions from the state have done so through a combination of violence and legal norms. ${ }^{260}$ Notable examples are the Sri Lankan Tamils and the Southern Peoples of Sudan. ${ }^{261}$

Eritrea is a special case study because of its brief colonial history. ${ }^{262}$ It can be said that in addition to the armed conflict, its independence was negotiated through international law. ${ }^{263}$ This is because Eritrea had previously existed as a former self-governing colony in terms of Chapter XI of the UN Charter when it was an Italian colony between 1889 and $1941 .{ }^{264}$

\section{Postcolonial Mimicry ${ }^{265}$}

As explained above, it would be difficult for the Ndebele to claim a right to autonomy, neither would it be prudent on the minority group to act outside international law. Thus any possible and constructive constitutional designs aimed at addressing the minority question ought to be located and negotiated within the Eurocentric discourse. Such an understanding necessitates a form of political pragmatism in the construction of a definition of minorities and their entitlement to either internal or external self-determination. ${ }^{266}$

\subsection{Defining Postcolonial Minorities}

A recurring point in this work is that a determination of an appropriate remedy for groups within a state who are numerically inferior to the rest of the population largely depends on how they are defined. ${ }^{267}$ Those classified as minorities have individual rights and it is often assumed that a progressive interpretation of the anti-discrimination clauses would accord individuals within such groups adequate protection. On the other hand, those classified as indigenous enjoy group rights including the right to self-determination.

It has also been stated that in the case of postcolonial Africa, this distinction is contested by both governments and minorities. Against this backdrop, postcolonial minorities who fit the description of European homeland minorities have

\footnotetext{
259) Heraclides, supra note 255.

260) Callahan, supra note 254.

261) Ibid., as read with Kymlicka, supra note 17.

262) Heraclides, supra note 255.

263) Ibid.

264) Article 73 UN Charter.

${ }^{265)}$ The terminology used here is borrowed from H. Bhabha, The Location of Culture. (Routledge, London 1995, 86).

266) Booysen, supra note 8 .

267) L. Thio, 'Battling balkanisation: regional approaches toward minority protection beyond Europe,' (2002) 43 Harv Int Law J 409.
} 
now resorted to the legal criteria for establishing that a group is indigenous in a bid to gain entitlements to collective special rights to education, land and selfgovernment which international law accords to indigenous peoples and not homeland minorities. ${ }^{268}$ Thus they have either resorted to self-identification as indigenous or are contemplating adopting these labels. ${ }^{269}$ From a postcolonial legal perspective, these groups appropriate the language of the law which provides self-identification as indigenous as a criterion for establishing groups which the ILO Convention on Indigenous people applies to. ${ }^{270}$ This could be a way of challenging the international legal discourse from within since acting outside it has resulted in further violations of the existential rights of disgruntled minorities.

On this note, Will Kymilicka gives an example of the Arabic speaking group which inhabits the Ahwaz region of Iran. ${ }^{271}$ This group which has persistently rejected the Iran's state's Persianiazation policies is of the view that their language is marginalized and also fear that the influx of Persians in their territory would lead to the loss of their identity. ${ }^{272}$ In the past, the group approached the Working Group on Minorities which failed to adequately raise attention to their plight thus they have self-identified themselves as indigenous and now participate in the work of the Working group on Indigenous people. ${ }^{273}$

This approach is however, unlikely to be supported by states who are the principal subjects of international law. ${ }^{274}$ Practitioners in postcolonial Africa are also less reluctant to embrace this model. ${ }^{275}$ For example, in 2005 the African Commission on Human and Peoples' Rights Working Group of Experts on Indigenous Populations/Communities raised objections to what it saw as the abuse of the term "indigenous." ${ }^{276}$ It wanted the term to be restricted to "[t] hose groups who experience particular forms of systematic discrimination, subordination and marginalization because of their particular cultures and ways of life and mode of production". 277

\footnotetext{
268) An example is the Aymara-speaking community of Bolivia, see A. Canessa, 'Who is indigenous? Selfidentification, indigeneity, and claims to justice in contemporary Bolivia,' 2007 36(3) Urban Anthropology 14.

269) Kymlicka, supra note 17.

270) This is based on Erica Irene Daes's 1982 third criterion for identification of indigenous people... an approach also followed in the 1989 ILO Convention Article 1(2) 169 Convention and 2001 World Bank Operational manual... see also 5(2) CERD General Comment on Article 27 and ILO Convention (No. 169) Concerning Indigenous and Tribal Peoples Convention in Independent Countries, art. 1, P 2, adopted 27 June 1989.

271) Kymlicka, supra note 17.

272) Ibid.

273) Ibid.

274) Ibid.

275) Report of the African Commission on Human and Peoples' Rights Working Group of Experts on Indigenous Populations/Communities, E/CN.4/Sub.2/AC.5/2005/WP.3.

276) Ibid.

277) Ibid.
} 
Nonetheless, self-identification as indigenous for the purposes of raising international awareness to post colonial's states' marginalization of groups which would otherwise be regarded as minorities has not been entirely futile. For example, partial victory can be claimed from the Ogoni's use of this strategy. ${ }^{278}$ The Ogoni of Nigeria labelled themselves as indigenous to draw attention to the concern that they and other groups who occupy regions where Nigeria draws its petroleum wealth do not get any economic benefit yet they are affected by the environmental hazards of oil extraction. ${ }^{279}$ This activism could be the reason why the 1999 Nigerian Federal Constitution included a clause to the effect that $13 \%$ of Nigerian oil revenue should be used in the regions where oil is extracted. ${ }^{280}$

Also, postcolonial states have employed this form of agency in their approach to land questions as a way of managing transitions from conflict. For example, post-apartheid South Africa adopted a nuanced version of "native" title to land, thereby extending the notion of indigeneity to groups which the classic international legal discourse does not consider to have a special attachment to land. ${ }^{281}$ The question which remains is the extent to which such agency can be extended to postcolonial demands for autonomy and self-determination.

\subsection{Postcolonial Quest for Autonomy and Self-determination}

The classic legal understanding is that minorities have no right to external selfdetermination, nor do they have a group right to internal self-determination although they can enjoy this individual right via democratic processes. As the earlier discussion indicated, in postcolonial contexts the application of these legal rules can be detrimental to peace and even the legal system itself. However, complete disobedience to this traditional legal understanding can only work in limited contexts where such conduct is in the interest of Western states. Thus post-conflict postcolonial societies have attempted a delicate balance whereby international law is made to fit the society's circumstances. ${ }^{282}$ Telling examples of such agency are South Africa and Northern Ireland (N.I) transitional clauses. ${ }^{283}$

The reference to N.I as postcolonial is not unproblematic since there is a prevailing view in both some parts of N.I and the Republic of Ireland that this is occupied territory. ${ }^{284}$ Nonetheless, it is also fair to state that the N.I conflict was

\footnotetext{
278) Ezetah, supra note 138.

279) Ibid.

280) Ibid.

281) J. Gilbert, 'Historical Indigenous People's Land Claims: A Comparative and International Approach to the Common Law Doctrine on Indigenous Title,' (2007) 56 ICLQ 583.

282) See Bell and Cavanaugh, supra note 3.

283) Ibid., see also Bell, supra note 85, K. Henrad, and Minority Protection in Post-Apartheid South Africa: Human Rights, Minority Rights and Self-Determination. Perspectives on the Twentieth Century Series, (Praeger, Westport 2002); Strydom, supra note 69.

284) D. Miller (eds), Rethinking Northern Ireland: Culture Ideology and Colonialism, (Longman, London 1998).
} 
similar to postcolonial "situations involving minorities" as it can be traced to the colonial encounter. ${ }^{285}$

In common with Rhodesia(now called Zimbabwe), Ireland was a British colony whose decolonization process was very complex as a minority revered Britain and did not consider majority rule to be ideal. ${ }^{286}$ In Rhodesia the white supremacists' Unilateral Declaration of Independence (UDI) of 1965 was not internationally recognized. Black majority rule was however, ushered in 1980 without any violation of the principle of territorial integrity. ${ }^{287} \mathrm{On}$ the other hand, the province of Ulster (presently referred to as Northern Ireland) was separated from the rest of Ireland in 1920 when two home rule parliaments were created in 1920 (Northern Ireland and Southern Ireland). ${ }^{288}$ This partition of the Island of Ireland into two was meant to accommodate the interest of the Unionist majority who wanted to remain British. ${ }^{289}$ Yet, Ulster also had two counties with allegiances to the Republic of Ireland, and it is this minority group's concerns which characterized the N.I troubles until the 1998 Good Friday Agreement. ${ }^{290}$

Christine Bell and Kathleen Cavanaugh have noted that the 1998 Good Friday Agreement is a very a good illustration of an innovative attempt at resolving a self-determination dispute. ${ }^{291}$ It can be said to have revised the self-determination norms as it contains both clauses which are informed by traditional notions of international law and those which are quite innovative in the sense that they go beyond conventional understandings of minority rights. ${ }^{292}$ This work recognizes this as evidence of postcolonial agency. ${ }^{293}$

Of significance is the provision that:

[I] $\mathrm{t}$ is for the people of the island of Ireland alone, by agreement between the two parts respectively and without external impediment, to exercise their right of self-determination on the basis of consent, freely and concurrently given, North and South, to bring about a united Ireland, if that is their wish, accepting that this right must be achieved and exercised with and subject to the agreement and consent of a majority of the people of Northern Ireland. ${ }^{294}$

On the face of it, this clause appears to be entrenched in international law since it makes it clear that N.I questions of external self-determination will be determined by the "demos" of Northern Ireland and not a minority group. ${ }^{295}$ It can

\footnotetext{
285) Ibid.

286) Ibid.

287) C. Palley, 'The Judicial Process: UDI and the Southern Rhodesian Judiciary', (1967) 30 MLR 263.

288) Miller, supra note 284.

289) Ibid.

290) Ibid.

291) Bell and Cavanaugh, supra note 3; Bell, supra note 85.

292) Bell, ibid.

293) For this paper's interpretation of agency see Bhabha, supra note 265.

294) Constitutional Issues; Belfast Agreement (1998), <http:// www.c-r.org>, accessed 10 June 2009.

295) Bell, supra note 85.
} 
also be said that the agreement also conforms to the contemporary international legal framework in its inclusion of clauses on equal rights for women and the protection for minorities within an individual human rights framework. ${ }^{296}$

Similarly, and in accordance with the U.N. Declaration and the Council of Europe Framework Convention for the Protection of National Minorities (Framework Convention), the agreement established a consociational government in the form of an assembly with power-sharing and mutual vetoes, to ensure that minorities effectively participate in decision making. ${ }^{297}$ Further adherence to the Framework Convention is also seen is the institutionalization of cross border contacts between Northern Ireland and the Republic of Ireland. ${ }^{298}$

A close scrutiny of the agreement however, reveal that it is in fact mimicry of international law since it offers a possibility for the deviation from the principle of territorial integrity. ${ }^{299} \mathrm{In}$ fact, the "demos" who are given possibilities for external self-determination are homeland minorities within the UK. ${ }^{300}$ It also breaches the sacred notion of sovereignty by embracing the idea of shared sovereignty between the Republic of Ireland and the United Kingdom. ${ }^{301}$ There are also special rights to ensure substantive and procedural equality. ${ }^{302}$ Further, power is disaggregated by the mainstreaming of civil society in the governance of society. ${ }^{303}$

Much more importantly, the implementation of the 1998 Good Friday Agreement was itself a form of self-determination since it was passed by way of a referendum. This referendum was subsequent to its endorsement by the parties to the agreement. ${ }^{304}$ This lesson could be exported to Zimbabwe where the GNU of 2008 which was accepted by the main political parties was signed after closed elite negotiations. There has been no opportunity for the people of Zimbabwe to accept the GNU as a means of facilitating the country's move from authoritarian rule to majority rule.

Innovation in the approach to minority related self-determination disputes also features in South Africa's constitutional framework which facilitated its transition from apartheid. ${ }^{305}$ Although, the process was itself an exercise in selfdetermination by the majority black population who have had a negative experience with programs aimed at promoting difference, concessions were made to those who still wanted to maintain their different identities. ${ }^{306}$ This is different

\footnotetext{
296) Ibid.

297) Ibid., as read with Bell and Cavanaugh, supra note 3.

298) Constitutional Issues; Belfast Agreement, supra note 294.

299) Bell, supra note 85.

300) Ibid., as read with Kymlicka, supra note 17.

301) Ibid., as read with Bell and Cavanaugh, supra note 3.

302) Ibid.

303) Ibid.

304) Ibid.

305) Henrard, supra note 283, as read with Strydom, supra note 69.

306) Ibid.
} 
from the Zimbabwean decolonization process were special rights were only accorded to the white minority whose continued presence in the country was considered to be of economic importance. ${ }^{307}$

It has already been pointed out that as in colonial Rhodesia; South Africa has a history of a centralized racialised state with power concentrated on the white minority. ${ }^{308}$ Similarly, the South African black community was united in as far as they resisted "white rule" but were far from being homogenous. ${ }^{309}$ This fact was acknowledged in the interim Constitution which officially recognized 11 languages. ${ }^{310}$

The constitutional model adopted during South Africa's transition from apartheid has a liberal tenor. ${ }^{311}$ This formula was, however, modified in two ways. Firstly, special rights were accorded to linguistic, cultural and religious minorities. ${ }^{312}$ Secondly, the possibility for autonomy or self-government was extended to groups which are not the typical "peoples" for whom international law extends the right to self determination. ${ }^{313}$ In fact, the present South African Constitution accords two forms of self-determination to minorities. ${ }^{314}$ These are possibilities for self-government and the limited right to cultural self-determination. ${ }^{315}$

This approach was a product of a process of attempting to strike a delicate balance between competing aspirations of self-determination which took place in the period between Nelson Mandela's release from prison in 1990 and the democratic elections of $1994 .{ }^{316}$ In that epoch, the majority ANC party's aspired for a democratic, multi-racial centralized state. ${ }^{317}$ On the other hand, minorities' opposition parties' who included right wing Afrikaner parties and the Zululand based party led by the Inkatha Freedom Party vowed for autonomy within or without the existing borders. ${ }^{318}$

In the initial stages the law largely conformed to paradigmatic notions of international law as it emphasized equality and democracy. ${ }^{319}$ This is evidenced by the

\footnotetext{
307) Lancaster House agreement, supra note 173.

308) Oomen, supra note 8.

309) Ibid.

310) Article 3, Constitution of the Republic of South Africa, Act 200 of 1993.

311) B. Oomen (1998); H. Booysen (1996-1997) supra note 8.

312) S31, Constitution of the Republic of South Africa, 1996. The exercise of those rights ought to be compatible with the rest of the constitutionally enshrined rights. Unfair discrimination by both the state or any other person on the basis of inter-alia, race, ethnic or social origin, colour, language religion and so on is prohibited. There is also a Constitutional requirement for the establishment of a mechanism for the promotion of such special rights for minorities so as to ensure peace and community cohesion. Furthermore, there was a constitutional requirement (which has since been complied with) for the enactment of legislation for the prohibition and prevention of discrimination by non-state actors.

313) Oomen; Booysen, supra note 8.

314) J.D. Van der Vyver, 'Cultural Identity as a Constitutional Right in South Africa' (2003) 14 Stellenbosch L. Rev. 51.

315) Ibid.

316) Oomen, supra note 8.

317) Ibid.

318) Ibid.

319) Ibid.
} 
substance of the initial Constitutional Principles (CP) on self-determination which was inserted into the South African Transitional/Interim Constitution of 1993. ${ }^{320}$ These include the constitutional principle which provided that: " $[\mathrm{P}]$ rovision shall be made for participation of minority political parties in the legislative process in a manner consistent with democracy". ${ }^{321}$

As in Zimbabwe's transition to black majority rule, the first concessions to be made to minorities were for appeasing the economic important white groups. Thus white civil and security force members were given job and pension guarantees. ${ }^{322}$ There was also amnesty for atrocities committed during the apartheid era. ${ }^{323}$ The major difference between the two countries guarantees to the white minorities could be attributed to the fact that during the negotiation stage the right wing Afrikaner parties boycotted the process on the basis that it had not factored in their quest for a territorial based homeland (Volkstaat). ${ }^{324}$ This may have also given impetus to the Zulu's demands for a tribal kingdom. ${ }^{325}$

When it became apparent that the Zulu and Afrikaner demands would threaten the peace process, last minute amendments were inserted to the Interim Constitution. ${ }^{326}$ Thus the amendment to $S 160$ of the Interim Constitution to include a provision that:

[a] provincial constitution may-(a) provide for legislative and executive structures and procedures different from those provided for in this Constitution in respect of a province; and (b) where applicable, provide for the institution, role, authority and status of a traditional monarch in the province, and shall make such provision for the Zulu Monarch in the case of the province of KwaZulu/ Natal. $^{327}$

In addition, CP XXX1V provided for: "[ $\mathrm{t}]$ he right to self-determination by any community sharing a common language and cultural heritage, whether in a territorial entity within the Republic or in any other recognized way". ${ }^{328}$ The adequacy and acceptability of these principles have been discussed elsewhere. ${ }^{329}$ It suffices to point out that South Africa did not hold firm to the notion of territorial integrity neither did it restrict the right to internal self-determination onto indigenous peoples. ${ }^{330}$ Thus its transitional Constitutionalism was mimicry of the international legal discourse. This form of agency could be exported to

\footnotetext{
320) Constitutional Principles; Constitution of the Republic of South Africa, Act 200 of 1993.

321) CPXIV, Constitutional Principles; Constitution of the Republic of South Africa, Act 200 of 1993.

322) Oomen, supra note 8.

323) Ibid.

324) Ibid.

325) Ibid.

326) Ibid.

327) S160 Constitution of the Republic of South Africa, Act 200 of 1993.

328) CP XXX1V Constitution of the Republic of South Africa, Act 200 of 1993.

329) Oomen, Booysen, supra note 8.

330) Ibid.
} 
neighbouring Zimbabwe so as to pre-empt the instability which is likely to be caused by the Ndebele marginalization.

\section{Conclusions}

This article has demonstrated that the current thrust of international law as seen in the definition of minorities is to integrate the new Western minorities who are the immigrants. The definition of indigenous people also shows the law's emphasis on correcting historical land injustices which were perpetrated by the descendants of the majority groups in Western society against the autochthonal peoples. Existing legal standards do not confer external self-determination to postcolonial minorities; neither do they give them a collective right to internal self-determination. At the same time, it is a fact that the post-colonial nation state was imposed on the minorities.

Nonetheless, minorities exist in postcolonial societies even though this nomenclature is unpopular with both postcolonial governments and those communities which are presumed to be such in international law. As stated above, some postcolonial governments deny the existence of minorities because there are afraid that any promotion of difference would point to both their illegitimacy and tendencies to be authoritarian. Minorities also resist this classification because its only benefits are the state-centric weak individual rights entitlements, which in most cases facilitate the postcolonial states' preference for assimilation as a way of managing diversity. Their categorization as numerically inferior has also been confused with de facto citizenship inferiority.

The Ndebele experiences illuminate these concerns. Indeed, in common with their compatriots in other postcolonial societies, those who champion the Ndebele cause have cited the colonial history and post-independence human rights abuses as the basis for their demands. Further, even though the Ndebele issue might be deemed to be at the periphery of the current Zimbabwean crisis, it cannot be cursorily thrust aside since a plethora of organizations fighting this cause are already in existence. Their demands are fortified by the fact that both the opposition and ZANU PF government do not seem to prioritize the need to endorse an unbiased historic record of the Gukurahundi genocide which might give closure to the Ndebele.

It is this legacy of impunity and state sanctioned amnesia which has bolstered this community's demands for internal and external self-determination. In an international legal system which applies equally to all, secession would be ideal since the group has a shared culture and is territorially based. In any event, a Ndebele monarchy which was divorced from the rest of the Shona territory existed before colonialism. Further, this community has fewer prospects of effectively participating in the country's governance. 
The international legal reality however, is that beyond colonization the collective right to internal self-determination has only been extended to indigenous peoples and not minorities. In addition, notwithstanding the inroads which globalization has made to the principles of sovereignty and territorial integrity, these notions are still sacred. There is a general resistance to any efforts that seek to disrupt the international order. Thus lessons could be borrowed from hybrid selfdetermination methods which were employed in the South African and Northern Ireland transitional case studies which are mimicry of the dominant discourse. It has in fact been said that this is an emerging norm for dealing with ethnic conflict in postcolonial transitions. ${ }^{331}$

Therefore, it is unfortunate that the traditional international legal discourse does not allow postcolonial minorities similar opportunities to the European experience when group protection under the League of Nations, facilitated the nation-building exercises of states which emerged after World War 1 . This need is imperative since postcolonial states have demonstrated that they would not hesitate to violate both the physical integrity rights and economic, social and cultural rights of minorities in their bid to reign in those communities seen as a threat to state's stability and their rule.

331) Bell, supra note 85. 